\title{
Competitiveness of the BRICS Countries on the Field of International Higher Education
}

Anita Veres

MTA-PE Networked Research Group on Regional Innovation and Development Studies, Hungary

\begin{abstract}
The aim of this study is to examine the higher education of BRICS (Brazil, Russia, India, China and South Africa) countries from the perspective of international student mobility and international competitiveness. The WEF-GCl, the UNESCO and the QS database provided data for the analysis. The extracted data were analyzed using descriptive statistical comparative and time series analysis methods. The study reveals the strengths and weaknesses of the higher education systems of the BRICS countries. The higher education of this group of countries could not be considered homogeneous. Brazil, China and South Africa are the strongest on the subfield of academic reputation, Brazil and China in the employer reputation, India in the citations per faculty while Russia in the faculty-to-student ratio and reception of students outside of the country. However, internationalization in general is a strategic area that needs improvement in all these countries. The goal of this research is to give a brief summary of the position of the BRICS countries in the field of international student mobility.
\end{abstract}

Keywords: BRICS, higher education, competiveness, ranking, development, society JEL classification: I21 , 125, F60

\section{Introduction}

As the result of internationalization, the higher education institutions of all developed and emerging-countries are influenced by the acceleration of the process of globalization. Higher education has the core objectives as an enterprise, to satisfy the domestic demand while creating a competitive position on the international markets.

The main factors of economic development in emerging countries are the quality of the human capital and knowledge (Boda et al., 2009). The analysis of the quality of human capital of the developing countries - including the assessment of the quality and the potential of education - could help to better understand their possibilities and to put to good use the fifth factor of production, the innovation (OECD, 2007).

This research focuses on the role and competitiveness of BRICS countries on the field of international student mobility in higher education. The main research question is whether there is a significant correlation between the international student mobility and the competitiveness of the BRICS countries. The paper highlights the position of the BRICS countries in the field of international student mobility.

The first part of this paper summarizes the history of the establishment of BRICS organization and highlights the common goals on the field of education. Also, this part describes the competitiveness of these countries using the global competitiveness rankings data. 
The first half of the analysis highlights on the WEF GCI 2013-14 overall ranking score, the $5^{\text {th }}$ pillar (higher education and training) score value and the UNESCO's Net flow of internationally mobile students' headcount data. The second part analyzed the UNESCO 2013 in bond - out bond student mobility data for the BRICS countries using the Gephi network analysis program. The purpose of the analysis was to determine the country of origin of the influx students in the BRICS countries and the country of destination of the out flux students from the BRICS countries.

Figure 1

Geographical Location of BRICS Countries

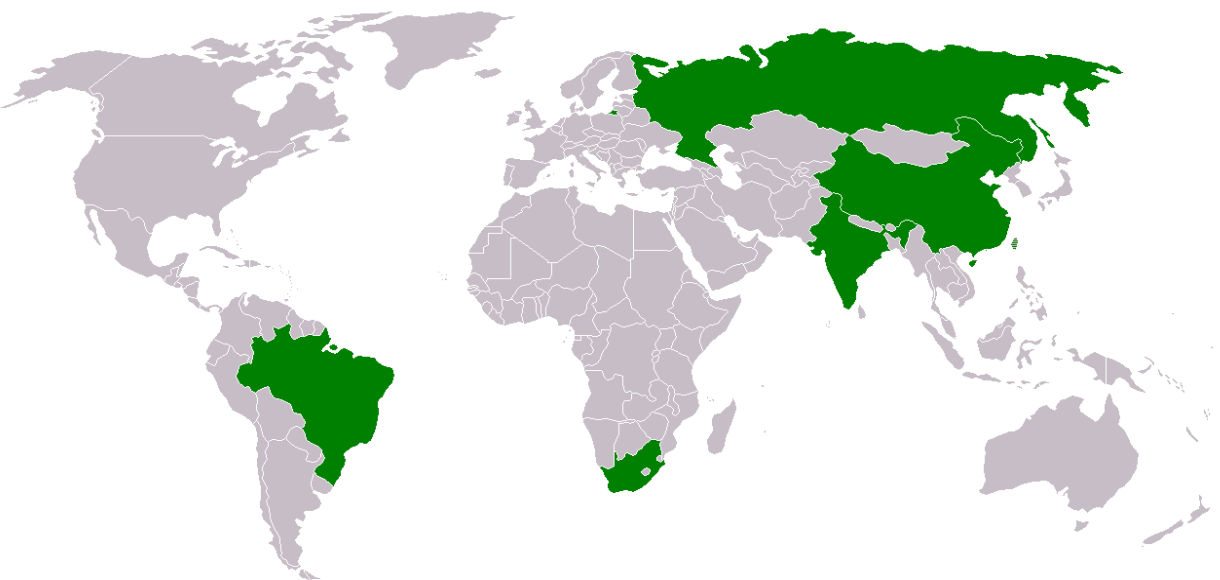

Source: Google maps' illustration

In 2001, Jim O'Neill chief economist of Goldman Sachs used the first time in his analysis of emerging economies the acronym BRIC to describe Brazil, Russia, India and China (O'Neill, 2001).

Their high level of economic development and accelerated "catching up" differentiates the BRICS countries from other emerging countries. Interestingly, despite that there are great differences in the historical heritage and economic backgrounds, these countries formed an entity in 2009. Ever since in 2010, South Africa joined the BRIC, the BRICS countries are represented on three continents (Mészáros, 2012)

They play key roles in the evolution of globalization and the development of new economic poles (BRIC Forum, 2009).

In addition to their role in the globalization processes, their regional leadership role is also considerable. Empirical studies of economic processes assume that globalization and regionalization are conflicting economic processes (Lorenz, 1991, Hirata et al., 2013), but analyses using network theoretical methods shows that the evolution of globalization and regional networks are closely related (Zhou et al, 2014th).

Based on the World Economic Forum's Global Competitiveness Report one could incorrectly conclude that the changes in the competitive rank of Brazil, India and South-Africa signal their economic decline. However, this was only due to the variations in the number of the countries studied, overall all the studied countries proved to be more competitive overall in 2013 compared to the 2003-04 ranking. 
Table 1

The BRICS Countries - WEF GCl-Ranking of Competitiveness

\begin{tabular}{llllll} 
WEF GCI & Brazil & Russia & India & China & South-Africa \\
\hline $2003-04$ & 54 & 70 & 56 & 44 & 42 \\
$2008-09$ & 64 & 51 & 50 & 30 & 45 \\
\hline $2013-14$ & 56 & 64 & 60 & 29 & 53 \\
\hline
\end{tabular}

Note:The WEF GCl ranked 102 countries in 2003, 133 countries in 2008 and 146 countries in 2013.

Source: WEF-GCl $(2003,2008,2013)$

Russia and China had greatly improved their competitive positions while Brazil and India's were essentially unchanged. Only South Africa experienced a slight decline over the years (WEF 2003, 2008, 2013).

Since the inception of the BRICS - between 2009 and 2015 - seven meeting took place between the countries. Goals and objectives regarding scientific cooperation and education were included in the founding document of the organization, but they were only vaguely described (BRIC Forum, 2009). There were no further discussions about the area of education in the documents of the next two forums (BRIC Forum, 2010, BRIC Forum, 2011).

Finally, the fourth meeting, in New Delhi, opened channels of communication between the BRICS countries regarding the following areas: the situation of young citizens, education, culture, tourism and sports (BRICS Forum, 2012).

On the fifth meeting of BRICS, under the name of "Education, research and skill development of the industrialized economies" concrete objectives were formulated (BRICS Forum, 2013).

In 2014, the concept of BRICS University Network was introduced (BRICS Forum, 2014).In 2015, the seventh meeting of the BRICS Forum discussed the topics of joining to the UNESCO Education -2030 program, and shaping the principles of the regulations of BRICS Network University (BRICS Forum 2015, UNESCO).

According to documents, the field of education development was only minimally discussed and covered since the first forum of BRICS seven years ago. Their goals, in essence, are only aimed to adapt already existing, working systems and applications of the Organization for Economic Co-operation and Development (OECD).

The higher education of this group of countries could not be considered homogeneous. Brazil, China and South Africa are the strongest on the subfield of academic reputation, Brazil and China in the employer reputation, India in the citations per faculty while Russia in the faculty-to-student ratio and reception of students outside of the country. However, internationalization in general is a strategic area that needs improvement in all these countries (WEF, 2013-14)

Based on the recent OECD report, China is spending more on research and development than any other country, even more than the US (OECD, 2015). The Russian Government focuses on the internationalization of its higher education, with a focus on gaining better university rankings globally. Meanwhile, India is planning to establish 14 world-class universities (QS, 2015).

\section{Methodology}

In the first half of the analysis, the WEF GCl 2013-14 overall ranking score, the $5^{\text {th }}$ pillar (higher education and training) score value and the UNESCO's Net flow of internationally mobile students' headcount data were used. Because of the limited 
number of countries who not only provided data for student mobility, but were also ranked by WEF-GCl, only 86 countries data were used in this analysis.

The purpose of the correlation analysis was to investigate the connections between net export and import student data, the overall competitiveness ranking and the $5^{\text {th }}$ pillar. The main question to answer was that is it true that more economically competitive countries are more likely to serve as host countries to international students?

In the second part, the UNESCO 2013 in bond - out bold student mobility data for the BRICS countries was analyzed using the Gephi network analysis program. The purpose of the analysis was to determine the influx and out flux of the students of the BRICS countries. Where the students are coming from to the BRICS countries and where the students are going to study from the BRICS countries?

\section{Results}

In this part of the analysis, the WEF GCl 2013-14 overall ranking score, the $5^{\text {th }}$ pillar (higher education and training) score value and the UNESCO's Net flow of internationally mobile students' headcount data were used.

Table 2

Correlation between the WEF Competitiveness, the $5^{\text {th }}$ Pillar and UNESCO's Net Value of International Student Mobility Data (number of countries analyzed: 86)

\begin{tabular}{ccccr}
\hline Spearman's & & $\begin{array}{c}\text { Net flow of } \\
\text { students } 2013\end{array}$ & $\begin{array}{r}\text { WEF Ranking } \\
2013\end{array}$ & $\begin{array}{r}5^{\text {th }} \text { Pillar } \\
\mathbf{2 0 1 3}\end{array}$ \\
\hline $\begin{array}{c}\text { Net flow of students } \\
2013\end{array}$ & $\begin{array}{c}\text { Correlation } \\
\text { Coefficient }\end{array}$ & 1,000 & $.387^{* *}$ & $.508^{* *}$ \\
$\begin{array}{c}\text { WEF Ranking } \\
2013\end{array}$ & $\begin{array}{c}\text { Correlation } \\
\text { Coefficient }\end{array}$ & $.387^{* *}$ & 1,000 & $.883^{* *}$ \\
\hline $\begin{array}{c}5 \text { th Pillar } \\
2013\end{array}$ & $\begin{array}{c}\text { Correlation } \\
\text { Coefficient }\end{array}$ & $.508^{* *}$ & $.883^{* *}$ & 1,000 \\
\hline
\end{tabular}

Note: ${ }^{* *}$ Correlation is significant at the 0.01 level (2-tailed)

Source: WEF-GCl 2013, UNESCO 2013

The first part of the analysis indicated that the correlation coefficients significant at 0.01 level, and the Pearson correlation test shows a moderate positive correlation between the overall competitiveness ranking, the $5^{\text {th }}$ pillars and the net international student population data.

The correlation between $\mathrm{GCl}$ and the $5^{\text {th }}$ pillar values should not be considered, because the $5^{\text {th }}$ pillar is part of the overall competitiveness index value. The analysis suggests significant connection between the quality of higher education and the net student flow. 
Figure 2

Higher education - international student flow data - BRICS countries, 2013

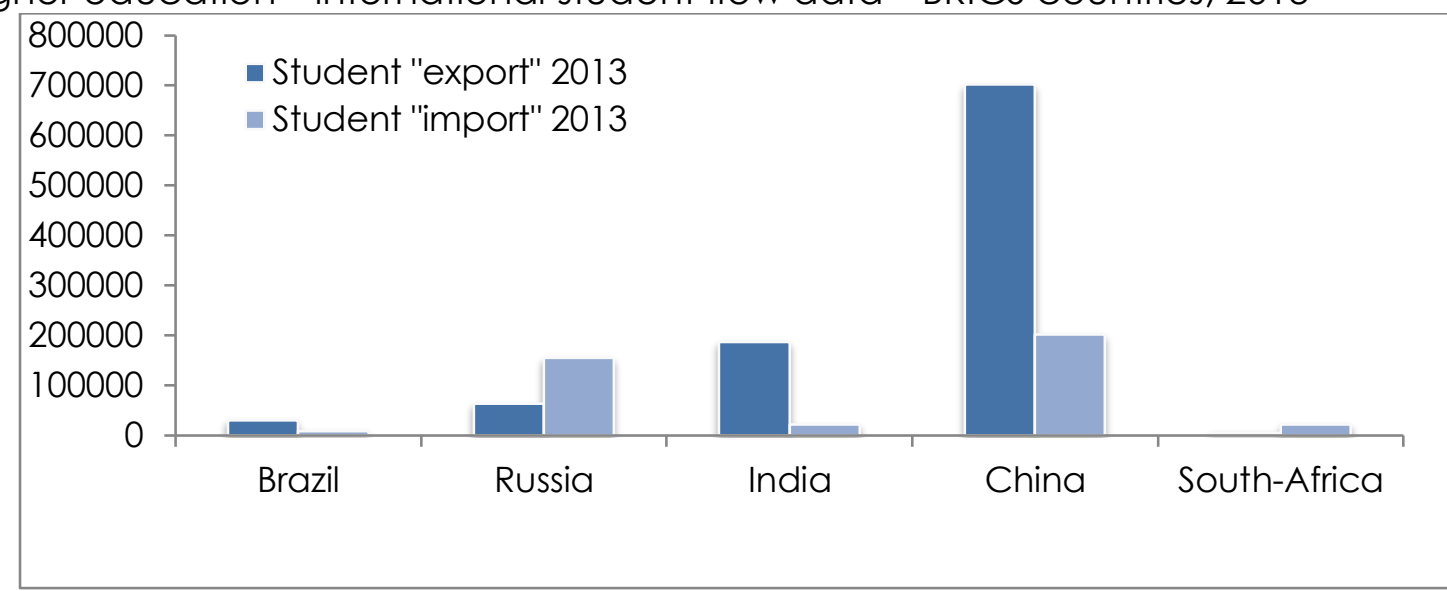

Source: UNESCO Database, 2013

The international students flow shows that in 2013, India and China wasthe most significant student exporting countries from BRICS. China became from a student sending country, to a student's sending and receiving country in the last decade. Brazil's and South-Africa's position in international student mobility flow were the least significant within BRICS.

Figure 3

BRICS - Top 10 students 'exports' destinations from BRICS in 2013

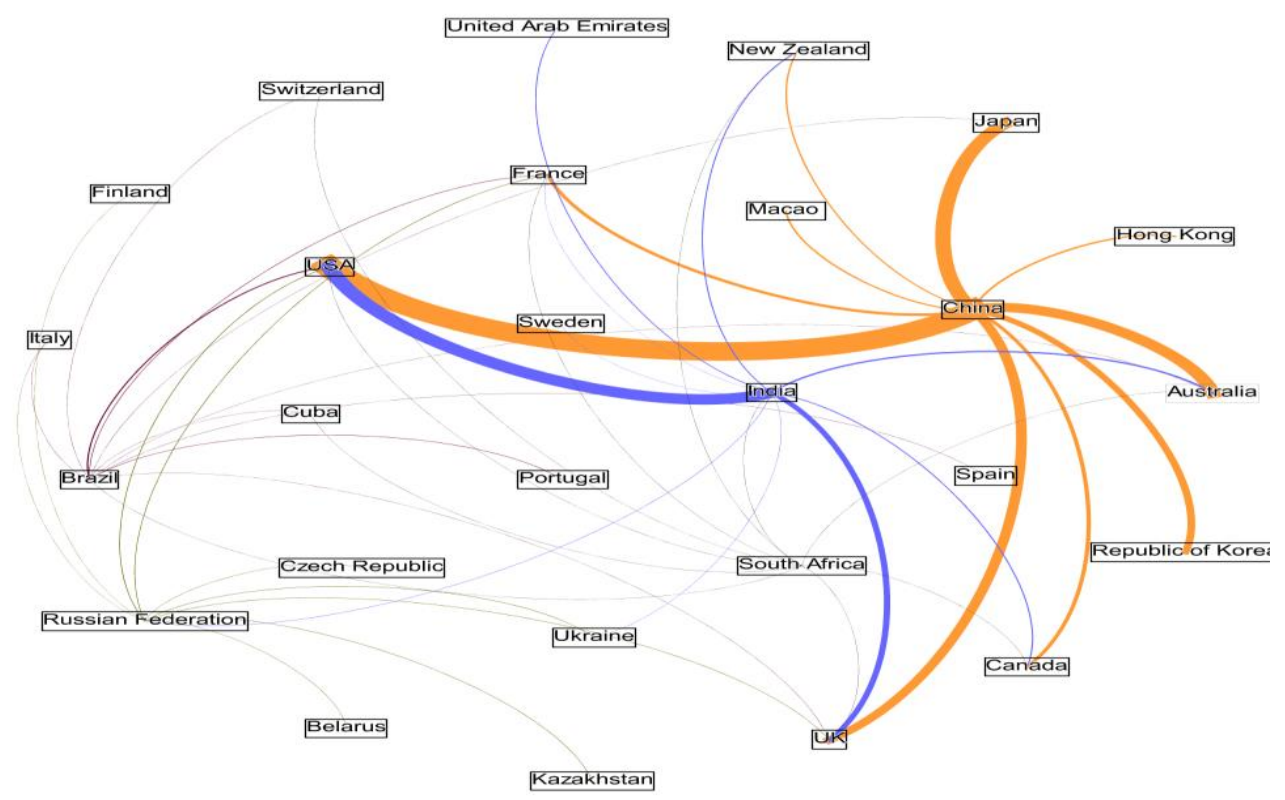

Source: UNESCO database, Author's illustration

South Africa is mainly a regional hub to other African countries, but it has no important role in the international student mobility as a student sending country. The most important target countries of university students from the BRICS were the USA, UK, Australia, Canada, France and Japan in 2013. 
Figure 4

BRICS - Top 10 students 'importer' countries to BRICS in 2013

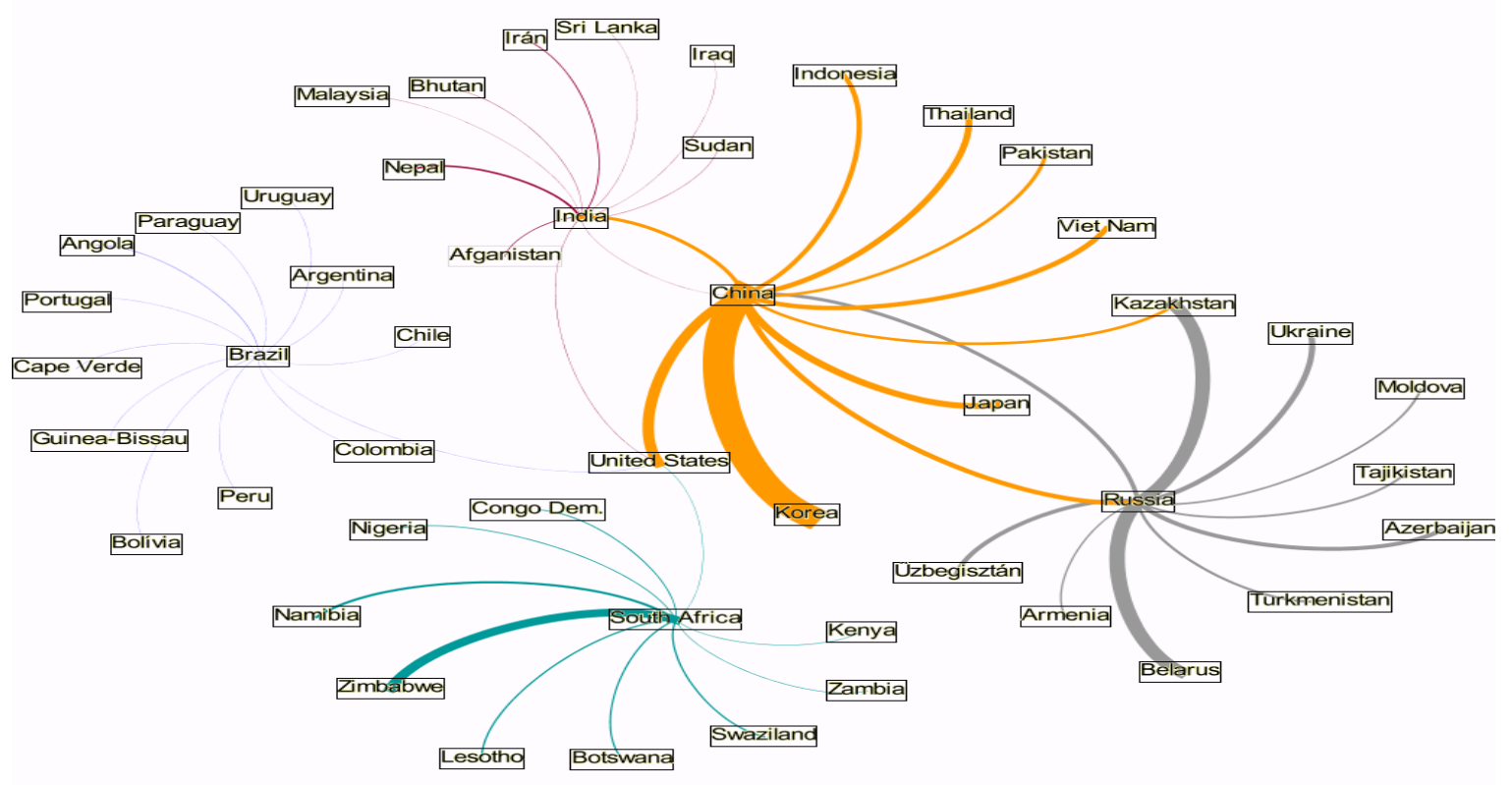

Source: UNESCO Database, Author's illustration

The student influx analysis indicates that all BRICS countries are major targets for regional students. However, the most important target countries of university students within the BRICS are definitely Russia, Republic of South Africa and China. The thicknesses of the edgesare proportionate to the flux of the students in the international student mobility network.

The surrounding countriessupply the majority of international students to the BRIC countries. In case of Russia this effect magnified by the common language and historical heritage shared with its neighbors.

Similar research had conducted by Chen at el (2000), where 64 countries were analyzed based on their role in the international student mobility network. It was found that the students' movement in the years of 1985, 1989 and 1995 remained relatively stable. The main centers of the international student flow were the US and most Western developed countries. The Eastern European and Asian countries were approaching towards the main contact points. African and Middle Eastern countries remained on the periphery.

Another research by Choudaha and Chang (2012) focused on the position of the four most important host countries (USA, UK, Australia and Canada) from the perspective of the international student enrolment of Indian and Chinese students. The number of student from China and India were increased. However the total number of international students declined in the leading host countries. 


\section{Conclusion}

The establishment of common international relations on the field of higher education in the BRICS countries is still at a very early, rudimentary phase. The BRICS countries can still be characterized by country specific educational targets.

In the international student flow, the BRICS are still mainly student exporting countries. However, China's position significantly changed in the first decade of the 21st century. China transformed from a student sending country, to a student's sending and receiving country. Despite of their low overall international ranking, all of the BRICS countries are regional leaders, significant destinations for students from their neighboring countries. When the international student mobility flows are also taken into account, Russia, South Africa and China prove to have dominant regional positions. The continuation of this research will focus on the leading universities of the BRICS countries and their role in the international student mobility.

\section{References}

1. Boda, Gy., Juhász, P., Stocker, M. (2009), "A tudás mint termelésitényező"Közgazdaság, Vol 2009/3, pp. 117-132, available at: http://unipub.lib.uni-corvinus.hu/291/1/9-boda-juhasz.pdf(4/14/2016)

2. BRIC Forum (2009), 1st BRIC meeting at Yekaterinburg, Russia, available at:http://www.bricsforum.com/yekaterinburg/ (16/6/2009)

3. BRIC Forum (2010), 2nd BRIC Summit of Heads of State and Government: Joint Statement Brasília, April 15, 2010, available at:http://www.bricsforum.com/brasilia/(16/6/2009)

4. BRIC Forum (2011), 3rd BRIC Summit, Sanya Declaration Sanya, Hainan, China, April 14, 2011 available at: http://www.bricsforum.com/sanya/ (4/14/ 2016)

5. BRICs and Beyond (2007), Goldman Sachs, 2007, p. 272.

6. BRICS Forum (2012), 4th BRICS Summit, New Delhi, India, on 29 March. 2012 available at: http://www.bricsforum.com/new-delhi/(4/14/2016)

7. BRICS Forum (2013), 5th BRICS Academic Forum 11th and 12th of March 2013 in Durban, South-Africa available at:http://www.bricsforum.com/durban/(4/14/ 2016)

8. BRICS Forum (2014), 6th BRICS Summit, Fortaleza, Brazil, on 15 July 2014, available at: http://www.bricsforum.com/fortaleza/(4/14/ 2016)

9. BRICS Forum (2015), 7th BRICS Summit, Russian city of Ufa in Bashkortostan on 8-9 July 2015, available at:http://en.brics2015.ru/documents/(4/14/2016)

10. Casella, P. B. (2011), „Brics - Brasil, Rússia, Índia, China e África do Sul - Uma perspectiva de cooperaçãointernacional" São Paulo: Editora Atlas, available at: http://funag.gov.br/loja/download/851-Catalogo Bibliografico BRICS.pdf(4/11/2016)

11. Chen, T. M., Barnett, G. A. (2000), "Research on international student flows from a macro perspective: A network analysis of 1985, 1989 and 1995", Higher Education Vol. 39 pp. 435-453: http://link.springer.com/article/10.1023\%2FA\%3A1003961327009\#page$1(4 / 11 / 2016)$

12. Choudaha, R., Chang, L. (2012) "Trends in International Student Mobility World Education News \& Reviews", Vol. 25 No.2, February 2012, available at: http://www.wes.org/RAS/TrendsInInternationalStudentMobility.pdf(4/1 1/ 2016)

13. Hirata, H., Kose M. A., Otrok, K. (2013), "Regionalization vs. Globalization" pp. 64. CAMA Working Paper 09/2013

14. Mészáros, R., (2012), "A BRIC országok, FöldrajziKözlemények" 2012. 136. 1. pp. http://foldrajzitarsasag.hu/downloads/foldrajzi kozlemenyek 2012136 evf 1 pp 037. pdf(4/14/2016)

15. Morazán, P., Knoke, I., Knoblauch, D.,Schäfer, T. (2012), "The Role of Brics in the Developing World. Directorate General for External Policies of the Union. EXPO/B/DEVE/FWC/2009/01/Lot5/24 April 2012, available at: 
http://www.ab.gov.tr/files/ardb/evt/1_avrupa_birligi/1_9_politikalar/1_9_8_dis_politika/ The role_of BRICS in the developing world.pdf(4/14/2016)

16. O'Neill, J. (2001), "Building Better Global Economic BRICs Global", Goldman Sachs, Economics Paper No: 66 pp 16, available at: http://www.goldmansachs.com/ourthinking/archive/archive-pdfs/build-better-brics.pdf (4/14/2016)

17. OECD (2007): "Insights - Human Capital: How what you know shapes your life", available at: http://www.oecd.org/insights/38430462.pdf (4/14/2016)

18. OECD (2015), "Research and Development Statistics" available at: http://www.oecd.org/innovation/inno/researchanddevelopmentstatisticsrds.htm (4/14/2016)

19. QS Report 82015), "University Rankings": BRICS 2015 - Overview, available at: http://www.topuniversities.com/university-rankings-articles/brics-rankings/as-universityrankings-brics-2015-overview(4/14/2016)

20. UNESCO Institute for Statistics Database 2003-2013 available at: http://data.vis.unesco.org/Index.aspx?queryid $=171 \#(4 / 14 / 2016)$

21. Utzig, S. M. (2014), "What Is the Mainstream of the BRICS? A Constructivist Analysis." Centro Universitário La Salle - Unilasalle, available at: http://brics.utoronto.ca/biblio/utzig-mainstream.pdf(4/18/2016)

22. World Economic Forum (2013), "The Global Competitiveness Report (2012-2013)". Schwab, K. (ed.), pp. 545.Online. Available at: http://www3.weforum.org/docs/WEF_GlobalCompetitivenessReport_201213.pdf $(4 / 14 / 2016)$

23. Zhou, S., Cerina, F., Chessa, A., Caldarelli, G., Riccaboni M. (2014), "The Rise of China in the International Trade Network: a community core detection approach", PLOS One 9, e105496 (2014), Available at: http://journals.plos.org/plosone/article?id=10.1371/journal.pone.0105496 (4/14/2016)

\section{About the author}

Anita Veres currently works as a researcher at MTA-PE Networked Research Group on Regional Innovation and Development Studies, while she is advancing toward her PhD in the field of economics at the University of Pannonia, Hungary. Her main research area covers fields of competitiveness of higher education. The author can be contacted at anitaveres@yahoo.com. 